\title{
Postprocessing of CL Data in CAD/CAM system Edgecam using the Constructor of postpro- cessors
}

Nadežda Čuboňová

Department of Automation and Production Systems, Faculty of Mechanical Engineering, University of Žilina, Univerzitná 1, 01026 Žilina, Slovakia. nadezda.cubonova@fstroj.uniza.sk

Introduction into problems - the present CAD/CAM systems integrate part modelling and engineering design, proposal of technological documentation in the form of $\mathrm{NC}$ programs and operational management of production within a one computer system. Their utilization allows the programmer to create machining technology, to define the tool paths and to generate NC programs for very complex shape parts [7]. Final product of CAM system is CL Data files, which include all the steps of toolpaths and technological process. If we want to connect the information produced by the CAM system with the concrete CNC machine, we need to use NC postprocessor. Generator of postprocessors to help users faster creates the specific postprocessor. Universal postprocessor does not exist. Unfortunately, it is necessary to create and to program it for each machine separately. This paper presents a use of the software tool "Constructor of postprocessors", by the creation of postprocessor in CAD/CAM system Edgecam. Postprocessor was developed for turning machine EMCO Concept Turn 55 with control system SIEMENS 840D at the Department of Automation and Production Systems (DAPS) Faculty of Mechanical Engineering.

Keywords: and lower case, normal, justified into block

Acknowledgement

This article was made under support of Grant Agency KEGA 071ŽU-4/2011 and VEGA1/0400/11.

\section{References}

[1] ČUBOŇOVÁ, N.: Počitačová podpora programovania CNC strojov, Monografia, EDIS ŽU v Žiline, 2012, ISBN 978-80-554$0514-8,115 \mathrm{~s}$.

[2] ČUBOŇOVÁ, N.: Počítačová podpora pro programování ř́idicího systému SINUMERIK 840D. In: Strojírenská technologie, Časopis pro vědu, výzkum a výrobu, duben 2012, č.1 a 2, ročník XVII, ISSN 1211-4162, s. 8-13.

[3] ČUBOŇOVÁ, N. Možnosti postprocessingu CL dát v CAD/CAM systémoch. In. Údržba, Vydáva Slovenská spoločnost' údržby, december 2011, ročník X,číslo 4, str. 5-7. ISSN 1336

[4] ČUBOŇOVÁ, N.: Technological possibilities of CAM system by the sheet parts production In: Academic Journal of Manufacturing Engineering, Editura Politechnika, Romania vol.7, ISSUE 3/2009, p.18-23.ISSN:1583-7904

[5] JANDEČKA, K. et al. Postprocesory a programování NC strojů. vyd. Fakulta výrobních technologií a managementu, UJEP. SPN, 2007. ISBN 978-80-7044-870-0, $244 \mathrm{~s}$.

[6] JANDEČKA, K. - ČESANEK, J. - ŠKARDA, J.: Postprocessor of CAD/CAM System Cimatron and New Types of Interpolation. In: Manufacturing Technology, Volume VI, December 06, pages 34-40, ISSN 1213248-9

[7] KURIC,I.: New methods and trends in product development and process planning. In: Academic Journal of Manufacturing Engineering, Editura Politechnika, Romania, Volume 9, Issue 1, 2011, Pages 83-88, ISSN: 1583- 7904

[8] MADL,J.: Design for Machining In: Manufacturing Technology, Volume IX, December 09, pages 81-86, č.M200910, ISSN 1213248-9

[9] NÁPRSTKOVÁ, N. - JANDEČKA, K. Programování výrobních strojú. Skriptum. Ústí nad Labem, 2010. ISBN 978-80-7414$216-1,142$ str.

[10] NÁPRSTKOVÁ, N.:Using of Catia V5 Software for Teaching at Faculty of Production Technology and Management. In Proceedings from 10th International Scientific Conference Engineering for Rural Development, Volume 10, p.554-557, ISSN 1691-3043, Jelgava, Latvia University of Agriculture, May 2011, Faculty of Engineering,

[11] POPEOVÁ, V., ČUBOŇOVÁ, N. et al.: Automatizácia Strojárskej Výroby. vyd. ŽU, EDIS: SPN, 2002. 230 s. ISBN 80-807009-5.

[12] ROKYTA, L. - BILEK, O.: Casting Die in CATIA In: Manufacturing Technology: Volume 12, 2012, pages 80-82, No. M201218, ISSN 1213-2489

[13] About NC Post-Processing. Dostupné na internete: [online]. 2012. [cit. 2012-7-27] http://polynet.dk/cadcam/cam/nc/about_nc_post_processing.htm

Copyright $\odot 2013$ Published by Manufacturing Technology. All rights reserved

Paper number: M201330

Manuscript of the paper received in 2013-02-15. The reviewer of this paper: Jozef Novak-Marcincin. 